\author{
NAGY SZABOLCS \\ nagy.szabolcs.8200@gmail.com
}

főlevéltáros (Magyar Nemzeti Levéltár Veszprém Megyei Levéltára)

tudományos munkatárs (Magyar Tudományos Akadémia Lendület Trianon 100 kutatócsoport)

\title{
Az 1916-os erdélyi betörés egyes hatásai a háromszéki nemzetiségi együttélésre ${ }^{1}$
}

\author{
Some Impacts of the Romanian Invasion of Transylvania \\ in 1916 to the Ethnic Coexistence in Háromszék
}

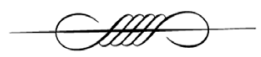

\begin{abstract}
The Romanian invasion of Transylvania in 1916 caused widespread damage to the concerned territory. Although the Romanian army was relatively soon pushed back from Transylvania, during the war, the architectural and economic restoration had to wait for long, and in many places could not be achieved. However, the effects of the fractures in society were at least as severe as the above mentioned damages. Until to the invasion, the Romanian-Hungarian coexistence appeared to be smooth-at least on the surface. The short Roman occupation, however, caused suspicions that questioned the loyalty of local Romanians and the small-numbered Hungarian-speaking population remained in Transylvania. The returning Hungarian authorities tried to resolve the situation by conducting prosecutions with charges of collaboration. However, the broken pseudo-cohesion could not be restored again under the Hungarian rule.
\end{abstract}

\section{KEYWORDS}

First World War, Transylvania, 1916, Romanian occupation, Romanians, collaboration

DOI 10.14232/belv.2017.3.3 https://doi.org/10.14232/belv.2017.3.3

Cikkre való hivatkozás / How to cite this article: Nagy Szabolcs (2017): Az 1916-os erdélyi betörés egyes hatásai a háromszéki nemzetiségi együttélésre. Belvedere Meridionale 29. évf. 3. sz. 33-41. pp.

ISSN 1419-0222 (print) ISSN 2064-5929 (online, pdf)

(Creative Commons) Nevezd meg! - Így add tovább! 4.0 (CC BY-SA 4.0)

(Creative Commons) Attribution-ShareAlike 4.0 International (CC BY-SA 4.0)

www.belvedere-meridionale.hu

${ }^{1}$ Jelen tanulmány az MTA Lendület Trianon 100 kutatócsoport munkája keretében készült. 


\section{BEVEZETÉS}

Ma már köztudott, hogy a szarajevói merénylet után gróf Tisza István magyar miniszterelnök ellenezte a hadüzenet elküldését, mivel tartott az esetleges vereség Magyarországra nézve súlyos következményeitől, elsősorban az ország feldarabolásától. ${ }^{2} \mathrm{Az}$ antant a háború megindulásától szerette volna elérni, hogy Romániai szövetségesei ellen forduljon, s támadja meg Erdélyt. A román fél ezt megígérni is csak nagyon hosszú tárgyalások után volt hajlandó, de a harcok megindításához végül az antant ultimátumára volt szükség. 1916. augusztus 27 -én este a román hadsereg megtámadta a jelentősebb erdélyi határállomásokat, megkezdte a behatolását az országba. ${ }^{3}$ A hadjárat sorsát a német és osztrák-magyar erősítés hamarosan megtörtént beérkezése megpecsételte. A két tűz közé került román hadsereg (délről a Mackensen vezette bolgár-német erők is megtámadták Romániát) hamar visszavonulásra kényszerült. Decemberben már Bukarest is elesett. ${ }^{4}$ A rövid hadjárat román szempontból nagy kudarcot hozott. Azonban a magyar fél is csak a hadisikereknek örvendhetett. Az erdélyi gazdaság és társadalom e rövid idő alatt is hatalmas károkat szenvedett. A támadás után a lakosság egy része elmenekült otthonaiból. ${ }^{5}$ Sajnos az egymásnak ellentmondó adatok miatt az elmenekültek pontos számát sem lehet rekonstruálni. A különböző becslésekről - nagyon szemléletesen - már a kortárs Nagybaczoni Nagy Vilmos is a következőket írta. „A menekülők száma nem ismeretes és ismeretlen marad örökké. Az akkori becslések is nagyon különbözöek voltak. Az 1. hadsereg magyar kormánybiztosa (Betegh) a menekülők számát 1 millióra, az akkori belügyminiszter, Sándor János 4-500.000-re, az 1. hadsereg parancsnokság pedig 1-200.000-re becsülte."”

Sajnos ma sem tehetünk mást, mint hogy egyetértünk Nagybaczoni majd' száz esztendős véleményével. Háromszék tekintetében azonban ha pontos számokat nem is, de az arányok érzékeltetésére szolgáló adatokat találhatunk. Sepsiszentgyörgy mintegy tizenegyezer lakójából például $A z$ Est beszámolója szerint mindössze ötszáznyolcvanhárman maradtak vissza. ${ }^{7}$ Számos településen azonban mindenki otthon maradt, vagy rövid menekülés után inkább a hazatérés mellett döntött. A Sepsi Református Egyházmegye később összeírta beosztott falvai vonatkozó adatait. Eszerint a harminckilenc település közül harmincból a többség elmenekült, hatba még a megszállás alatt visszatért a lakosság zöme, míg háromban a legtöbben eleve otthon maradtak. Megvizsgálva az egyes csoportokat, nem sikerült semmiféle szabályszerüséget felfedezni. Mindkét (három) csoportban vegyesen található eldugott, illetve forgalmas helyen található község. De a lakosság nemzetiségi összetételét illetően sem mutatkoznak tendenciózus különbségek, azon egyszerű oknál fogva, hogy a harminckilenc település túlnyomó részét jelentős többségben magyarok lakták. ${ }^{8}$

A témával kapcsolatban meg kell említeni, hogy a forrásokban szereplő személyek nemzetisége meglehetősen bizonytalan, mivel ilyen adatokat az iratok nem rögzítenek. Kivételt képeznek

\footnotetext{
2 IFJ. BERTÉNYI 2002.

${ }^{3}$ RAFFAY 1989.

${ }^{4}$ RAFFAY 1989.

${ }^{5}$ Ennek körülményeiről, a hadvezetés és a közigazgatás ellentétes szándékairól, egymásnak ellentmondó utasításairól ld. pl. Betegh 1924. 69., illetve NAGYBACZONi 1923. 72-74. A polgári lakosság, illetve a katonaság, valamint a hadianyagok kiürítéséről külön polgári, illetve katonai utasítások rendelkeztek.

${ }^{6}$ NAGYBACZONI 1923. 77.

Az Est 1916. szeptember 6. 2. Idézi: Csóti 2004.

${ }^{8}$ KovÁCs 1917.
} 
a visszaemlékezések, egyéb összefoglalások, melyek azonban - jellegükből adódóan - hajlamosak az általánosításra, egyszerüsítésre, így vonatkozó állításaik igazságtartalmával kapcsolatban csupán becslésekre szorítkozhatunk. Visszatérő motívum például, hogy a nemzetiségek között a menekülési hajlandóságot tekintve különbség volt, a románok jóval kisebb arányban hagyták el otthonaikat. A körülmények alapján valóban nekik volt a legkevesebb okuk a behatoló hadsereg elől menekülni, s talán nem is érdemes kételkedni abban, hogy többségük otthon maradt.

E feltevéssel egybevágnak például Balázsovich Sándor, sepsiszentgyörgyi patikusnak a megszállás alatt készült naplóbejegyzései, melyekben többször hangsúlyozta, hogy - a XVIII. századi telepítés óta szinte szín román - Előpatak lakossága egy emberként otthon maradt. ${ }^{9}$ Ugyanígy erősítheti véleményünket egy Csóti Csaba által közölt táblázat, melyből kiderül, hogy az ott feltüntetett megyék közül - az egyedüliként - döntő többségében románok által lakott $(88,71 \%)$ Fogaras vármegyében kiemelkedően alacsony volt a regisztrált menekültek száma $(3,52 \%) .{ }^{10}$ Érdemes még összevetni az előbbi adatot Szádeczky-Kardoss Lajos vonatkozó művének egy közlésével is: „Fogaras vármegye oláh népe volt a legfogékonyabb eleme az oláh irredenta bujtogatásainak. Radu Negru meséje, a Fogarasból kiköltözés és államalapítás ábrándképe megtermékenyitette az oláh fantáziát. A fogarasi pópák, dászkálok, banktisztviselök, mindmegannyi ügynökei voltak az oláh aspirációknak. A nép a határszél szomszédságánál fogva állandó érintkezésben volt a »czárával «" (ahogy ök Oláhországot emlegették)."12

\section{FosztogatÁsoK}

Az otthon maradók közötti vélt túlsúlyuktól nem függetlenül, a dokumentumok a fosztogatók esetében is a románok többségét feltételezték. A nyilvánvalóan túlzó, rémhírekre építkező írások mellett - bár árnyaltabb formában - de így van ez például a Balázsovich-féle naplóban is.

„Ma a város képe megváltozott, a magyarok visszahúzódtak, nem mertek mutatkozni, helyüket a vidékröl becsödült oláhság foglalta el, kik telt szekerekkel mentek haza."13

„Hazajövet ebédre találkoztam az aldobolyi oláh pappal, ki egy lovas szekéren jött. Délután bemenve a városba láttam, hogy a szövetkezeti üzletböl hordják az árut az elöpataki és árapataki oláhok. ${ }^{14}$ Bementek az üzletbe, $s$ egy oláh lovas kapitány biztatta a népet a fosztogatásra, s több társával együtt a tisztek is osztogatták az árut. Mikor már a sajtboritó üveget is odaadták, $s$ nem maradt egy doboz gyufa sem az üzletben, akkor átvezette a kapitány a népet a Kolcza üzletébe, ahonnan szintén elhordták még a csomagoló papirt is. Ott fosztogatott egy Kásás nevü volt hídvégi ember, ki most otthon lakik Elöpatakon, ki két kis szürke lovas szekérére hordta ki az árut. Ezután hozzám jött a patika elé, ahol én üldögéltem egyedül, s beszélte, hogy Elöpatakon kirabolták Domokos Miklóst, Domokos Ákost, Imecs Ernöt, Goldstein Józsefet, Goldstein Manót, és Bindert. Ennek folytán egy erös örjárat ment ki Elöpatakra, ki a néphez beszédet intézett, hogy örömmel jött Elöpatakra mert mióta Oláhországból eljött, ez az első oláh község, de másrészt szomorúsággal tapasztalja, hogy az elöpatakiak hogy rabolnak. "15

\footnotetext{
${ }^{9}$ NAgY 2011a.

${ }^{10}$ Csóti 2004. 56.

${ }^{11}$ Ţara, magyarul haza.

${ }^{12}$ SZÁdecZKY-Kardoss (é.n.). 155.

${ }^{13}$ NAGY 2011a. 323.

${ }^{14}$ Árapatak Előpatak mellett fekszik, Előpatakhoz hasonlóan azon kevés korabeli háromszéki település egyike volt, melyben jelentős számban éltek románok.

${ }^{15}$ NAGY 2011a. 322.
} 
„[...] maga a kapitány vezette a katonákat a fosztogatásra. Délfelé apró sovány lovakon részben szuronyos katonák, részben civilek érkeztek, s a piacon álltak meg. Ugyancsak a piacon velük összevegyülve az elöpataki oláhság, kiket tegnap egy kapitány értesitett, hogy ma is kapnak füszer árut. Ezeket azonban délután lovas katonákat hajtottak ki a városból, de az oláh pap két megrakott szekér árut is szállitott haza. Ma délelött tüzték ki az oláh lobogót a kaszinó ablakába, délután pedig a városháza kapuja fölé, hangos vivát kiáltással. "16

„Ma is tele volt a város elöpataki, árapataki, aldobolyi, dobollói oláhokkal, sárkosi oláh cigányokkal, kik mind tele zsákokkal mentek haza. Ma a szövögyári üzletböl szállitották az árut a volt árvaszéki épületbe. "17

„Az elöpataki oláhok ma is zsákban és lepedőben hordták a katonák által nekik ajándékozott árut. Megnéztem az Agrárhelyiséget, hol még a polc is össze van törve." 18

Mint látható, a naplóíró azt tapasztalta, hogy a román civileket a megszállók nem hogy akadályozták volna a visszaélések elkövetésében, de egyenesen bátorították, segítették őket. Természetesen nem tagadja el azonban a magyarok által elkövetett fosztogatásokat sem. Ezt annak tulajdonítja, hogy főleg a lecsúszott elemek maradtak otthon, akik így a csonka közösségekben kiszabadulhattak a társadalmi kontrol alól. „Árkoson, Köröspatakon és Kálnokon is az otthon maradt csőcselék rabol és rombol.” ", Borzasztó volt az oláh invázió, s legborzasztóbb volt az, hogy ily csöcselék között kellett maradni itthon.” Vagy másutt: ,, Rémes dolog most már harmadik héten át nézni ezt a lelketlen rablást, melyben az itt való nép is részt vesz suttyomban. És rémes dolog ily nép közt lakni. Mert intelligens, jó lelkü ember alig maradt a városon száz, a többi 3-400 öregasszony, s züllött-iszákos öregember, kik most semmit sem dolgoznak. ” Melik András honvédfőhadnagy szeptember 2-án kelt jelentése is hasonló jelenségről számol be: „, Gyergyó Ditró és Remete községekben múlt hó augusztus 29-én és 30-án az ottan lévő nagyrészt román származású csendörök és a trén fedezésére kirendelt mintegy zászlóalj cseh katonák együttértve boltokat, lakásokat, pincéket feltörtek, kifosztottak és az ott maradt lakosságtól állatokat, majorságot harácsoltak anélkül, hogy erröl írást adtak volna. Ezzel kapcsolatban azt is jelentem, hogy ezen dolgok látására a községben maradt csöcselék is neki bátorodott és szintén hasonló módon garázdálkodott az ottan maradt gazdátlan otthonokban. " ${ }^{20}$

A fenti és egyéb források alapján nyilvánvaló, hogy a visszaéléseket nem lehet csupán a helyi román civilekhez és a megszálló hadsereghez kötni. A háborús viszonyok, nélkülözések, megromlott közrend mellett ezek a jelenségek sajnos ,,természetesek” voltak, bármely nemzetiség tagjai követték is el őket. Mennyiségi és minőségi különbség azonban megállapítható. Egyrészt a civilek fosztogatásait segítő, ösztönző katonák képe meglehetősen furcsa. Ha nem is példa nélküli a jelenség, fegyelmezett hadseregben nem megszokott. A katonai alakulatok a hadmüveleti területeken karhatalmi feladatokat is elláttak, így kötelességük volt tenni a rendbontások ellen. Természetesen a román hadseregben is voltak felelősségteljesen viselkedő vezetők, akik végül felléptek az áldatlan állapotok ellen. ${ }^{21}$

De mutatkoztak különbségek a fosztogatások, rongálások mennyisége és motivációi tekintetében is. A sepsi református egyházkerület már idézett jelentéséből például kiderül, hogy

\footnotetext{
${ }^{16}$ NagY 2011a. 323.

${ }^{17}$ NAGY 2011a. 325.

${ }^{18}$ NAGY 2011a. 326.

${ }^{19}$ NAGY 2011a. 313.

${ }^{20}$ Idézi: PÁl-ANTAL 2003. 217.

${ }^{21}$ Pl. NAGY 2011. 326.
} 
a német és osztrák-magyar szövetségesek is okoztak károkat. Ezek azonban szinte kizárólag a szükségleteik kielégítése érdekében tett cselekedeteik következtében keletkeztek, például amikor kerítéslécből raktak tábortüzet. A román katonák viszont gyakorta céltalanul lerombolták azon értékeket, melyeket nem tudtak, vagy nem tartottak érdemesnek elvinni. Így például nagyon sok templomi berendezés esett fosztogatásaik céltalan áldozatául. ${ }^{22}$

\section{KOLLABORÁCIÓS VÁDAK}

A fosztogatók nemzeti hovatartozása csak áttételesen kapcsolódik az erdélyi románság lojalitásának kérdésköréhez. Történtek azonban olyan esetek is, melyek által az érintettek hazához való hűsége kérdőjeleztetett meg. A háborús viszonyok között az államellenes bűncselekmények egy köre a katonai büntetőbíróságok illetékességébe tartozott. A katonai büntető eljárásjogot - a hadsereg kettős szervezetének megfelelően, első ízben a magyar történelem folyamán 1912-ben két törvénycikk segítségével kodifikálták. A XXXII. törvénycikk a közös hadsereg, a XXXIII. pedig a honvédség büntető perrendtartásáról rendelkezett. ${ }^{23}$ Ez utóbbi 14. szakasza rögzítette, hogy mozgósítás vagy háború tartama alatt minisztériumi rendeletben lehetőség nyílik egyes, a polgári bíróságok illetékességébe tartozó bűncselekményeket a katonai büntetőbíróságok illetékességébe utalni. Ilyen deliktum volt a jogosulatlan toborzás, az esküvel fogadott katonai szolgálati kötelesség megszegésére csábítás, vagy segélynyújtás, a kémkedés és az ellenséggel való más egyetértés bűntette vagy a fegyveres erőnek vagy szövetséges csapatainak hátrányát vagy az ellenségnek előnyét célzó egyéb cselekmények, továbbá a katonai behívó parancs iránt engedetlenségre csábítás. ${ }^{24}$

Az elmenekült, majd a megszállás végeztével visszatért lakosok részéről nem volt ritka az otthon maradottak irányába mutatott megvetés, bizalmatlanság. Kollektív ítélték meg őket. Általános volt a vélemény, hogy azok kivétel nélkül együttműködtek a megszállókkal, a fosztogatásokon kívül egyéb büncselekményeket is elkövettek, , újrománok lettek”. Nem meglepő, hogy nagyszámú feljelentés is született velük szemben. Az aránylag nagyobb mennyiségben fennmaradt, a fenti bűncselekményi körbe tartozó, háromszéki ügyeket tárgyaló irat jó része ilyen feljelentés nyomán keletkezhetett. A források azonban sajnos nem az eredeti bírósági akták, hanem az eseteknek a vármegyei közigazgatás dokumentumaiban fennmaradt leiratai. A területen a Kolozsvári Honvéd Hadosztálybíróság rendelkezett illetékességgel. Az alább tárgyalt eseteket vagy közvetlenül ez, vagy a Kolozsvári Honvéd Katonai Ügyészség brassói kiküldött ügyésze vizsgálta. Sajnos ezen szervek korabeli iratai szinte teljesen elvesztek az utókor számára, így az alább idézett ügyeken kívül újabb háromszéki példák felbukkanása nem nagyon várható. ${ }^{25}$

Az ügyek terheltjeink etnikai hovatartozása meglehetősen kétséges, mivel a források azt nem rögzítették. Kézenfekvőnek tűnhet a nevekből kiindulni, ez azonban az asszimiláció miatt súlyos tévutakra vezethet. Egy későbbi, 1919. évi hírlapi közlés szerint például Selejan Demeter borosjenői kőművest - akinek családneve nyilvánvalóan román eredetű, de Dumitru formában

\footnotetext{
${ }^{22}$ KovÁcs 1917.

${ }^{23}$ A témára vonatkozóan vö. FARKAS 2011; KELEMEN 2013.

${ }^{24}$ FARKAS 2011.

${ }^{25}$ A fondok hiányáról, hiányos voltáról a Hadtörténeti Levéltár interneten elérhető fondjegyzékéből tájékozódhatunk. (http://militaria.hu/adatb/leveltariuj/f/04_iv_fondfocsoport_segedletei)
} 
keresztneve is elterjedt volt a románság körében - egy havi fogházra itélte a román haditörvényszék, mert a román nyelvről beszélve sértő szavakkal illette a román nemzetet. ${ }^{26} \mathrm{~A}$ későbbiekben ismertetett esetekben a szereplők nemzetiségét nagy valószínüséggel csak akkor lehet megállapítani, amikor az illető lakhelye szinte kizárólagos román etnikai túlsúllyal bírt.

Az ügyek első típusába azok tartoznak, melyek nagy valószínűséggel valamely visszatért szomszéd alaptalan feljelentése következtében indultak. Közös bennük, hogy valamennyi túlnyomó arányban magyar többségủ település magyar hangzású családnevet viselő lakója ellen zajlott le, így a terheltek minden bizonnyal magyarok voltak. A kézdisárfalvai Bajkó Ferencet például azzal vádolták, hogy a megszállókkal bor s muzsikaszó mellett mulatott, illetve a nőket főbelövéssel fenyegetve akarta a román katonákkal történő közösülésre kényszeríteni. Ezenkívül szerepelt a vádak között az is, hogy a románokkal közösen lopott, fosztogatott, illetve a többi otthon maradottat is bujtogatta az elmenekültek javainak kifosztására, s fuvarra kényszerítette az embereket. A vádakat végül ejtették, sajnos a döntés indoklása nem maradt fenn. ${ }^{27}$ Ugyanez történt Sinka György és Györgyné, valamint Hegyi Ferenc sepsibodoki lakosok estében, akik a vádak szerint raboltak, fosztogattak, sőt Hegyi Ferenc még a magyar érzelmủ helyieket is halálosan megfenyegette. ${ }^{28}$ Szintén felmentették Rusz János sepsibükszádi polgárt, aki a vádak szerint bíróságot vállalt, mindenféléről tájékoztatatta, illetve megvendégelte a megszállókat. ${ }^{29}$

Pár esetben szerencsére rendelkezésünkre állnak az indoklások is. Például Málnási Zsigmond ikafalvi lakost azzal vádolták, hogy megmutatott a románoknak egy rejtett erdei utat, illetve egy Matis Géza nevű személynél ételhez is segített egy eltévedt román csapatot. Málnási védekezésképpen előadta: ő ezeket kényszer alatt cselekedte, mivel miközben üzeneteket vitt különböző községekbe, hogy a katonaköteles férfiak kötelesek elmenekülni, egy román előőrs elfogta. Védekezését elfogadták. ${ }^{30} \mathrm{Az}$ illyefalvai Majláth János bírói tisztséget vállalt, illetve román karszalagot hordott, ami a Kolozsvári Honvéd Hadosztálybíróság véleménye alapján (kiváltképp, mivel a vádlott szerint ezt azért tette, hogy otthonmaradt társait hatékonyabban védelmezhesse) önmagában nem bủncselekmény. A Majláthot a fosztogatásokkal kapcsolatba hozó vádakat pedig bizonyítottság hiányában ejtette a bíróság. ${ }^{31}$ Ugyanígy a bodolai Serény József esetében, kit az a gyanú terhelt, hogy a bevonuló román csapatokat éljenezte és virágot vitt nekik. ${ }^{32}$

Az ügyek között mindössze egyetlen olyan esetet találtunk, melyben kollaborációs cselekményben egy - neve és lakhelye alapján - vélhetően magyar származású személyt találtak bünösnek. A kilyéni illetőségű Katona József, hatvannyolc éves asztalos, a Kolozsvári Honvéd Hadosztálybíróság döntése értelmében a katonai büntető törvénykönyv 327. §-ba ütköző, az állam hadiereje elleni büntettet követte el. ${ }^{33} \mathrm{Az}$ indoklás szerint a román invázió idején együttműködött a megszállókkal, magát községi bírónak neveztette ki. A román katonákat szívesen kalauzolta, velük közösen fosztogatott. Zoller Gizellát kényszerítette, hogy a románoknak nemzeti lobogót varrjon, magánál is kitüzte a román zászlót. A kapuján, mint román bíró aposztrofálta magát, illetve azon egy „Éljen Románia!” feliratot is elhelyezett. Amikor a magyar csapatok közelítettek

\footnotetext{
${ }^{26}$ Aradi Közlöny 1919. szeptember 2.

${ }^{27} 9 / 2 / \mathrm{a} / 156$ fond 47 . f.

${ }^{28} 9 / 2 / \mathrm{a} / 156$ fond 62 . $\mathrm{f}$.

${ }^{29} 9 / 2 / \mathrm{a} / 156$ fond 75 . f.

${ }^{30} 9 / 2 / \mathrm{a} / 157$ fond 81 . $\mathrm{f}$.

${ }^{31} 9 / 2 / \mathrm{a} / 156$ fond 107 . $\mathrm{f}$.

${ }^{32}$ 9/2/a/156 fond 38 . f.

${ }^{33}$ FARKAS 2011.
} 
a községhez, figyelmeztette erre a román csendőröket és segítette menekülésüket. Tetteiért, melyet a református esperes jelentése is közölt, tizenöt év börtönt kapott, minden hónapban egyszer kenyér-víz böjttel, kemény fekhellyel, illetve évi egy hónap magánzárkával súlyosbítva. ${ }^{34}$

A többi olyan személy, akit az eljárások során elítéltek, (a már ismertetett kritériumok alapján) vélhetően román származású volt. E vélekedésünket az is alátámaszthatja, hogy ezek általában a visszavonuló román csapatokkal tartottak, s csak távollétükben sikerült elítélni őket. Így történt Máté János sósmezői lakos esetében is, aki előbb segített egy román járőrnek elrejtőzni, majd segítségükkel tőrbe csalta a magyar járőrt. Ez utóbbi tagjai közül kettőt lelőttek a románok. Az ítélethirdetéskor Romániában tartózkodott. ${ }^{35}$ Szintúgy Csoflak Konstantin és Cincereán György volt árapataki lakosok, akik a megszállás kezdetekor a románok elé vonultak egyházi zászlók alatt, éltetve a megszállókat, illetve Nagyromániát. Ezt követően Brendus György községi bíró házában titkos gyüléseket tartottak, majd közremüködtek abban, hogy a románok elhurcolták magukkal a református papot, a prókátort és másokat, összesen hét személyt. Érdekes adalék az esethez, hogy Cincereán a magyar uralom alatt közgyám volt, árulása tehát magisztrátusként még súlyosabban esett latba. ${ }^{36}$

A mélyebb vizsgálódásokat mellőzve, szokás a 20. század elejének büntetőeljárásait kollektív elfogultként, koncepciózusként értékelni. Ezzel szemben a konkrét esetek elemzése során általában azt tapasztalja a kutató, hogy a bíróság - még az olyan, a szokásos jogállami garanciákat kevésbé nyújtó eljárás során is, mint a katonai perrendtartás szerint lefolytatott - mereven ügyelt az elő́rások, a jogszerűség betartására. A háromszéki eljárások közül ilyen például Bacsó Mária esete. A buzaui születésű, pákéi illetőségű huszonhat éves nőt annak ellenére felmentették, hogy esetében minden vádpont igazolást nyert. Az indoklás alapján ezt azért tették, mert cselekedeteit nem a románok, hanem a saját hasznára követte el. Ez pedig azt jelentette, hogy a bűncselekmény elkövetésének egy lényegi eleme hiányzott, mely hiátus miatt e cselekményt a jogszabály szerint nem lehetett a vádlott terhére róni. Pedig Bacsó a megszállókkal kialakított jó kapcsolatát felhasználva (a katonákkal erkölcstelen viszonyt folytatott), többek között egy embert fuvarozásra kényszeríttetett, főbelövetéssel, illetve a község felgyújtatásával fenyegetőzött, valamint kijelentette: „,Remélem Isten kipusztítja a magyar nemzetet! ”,37

\section{ÖSSZEGZÉS}

A rövid román megszállás okozta gazdasági károk miatt a háború végéig nem kártalanították a Székelyföld lakosságát. De erre legalább létezett reális cselekvési terv, a kárt szenvedettek reménykedhettek az enyhülésben.$^{38} \mathrm{~A}$ helyi magyar-román viszonyokon viszont olyan sebek estek, melyek a legjobb szándék mellett sem tudtak volna behegedni az újabb román megszállásig hátralévő szűk két évben. Az idézett forrásokból jól látszik, hogy a menekülésből visszatérők legtöbb sérelmüket - az elterjedt vélekedés szerint szinte ,, kollektiv” otthon maradt - románsághoz kötötték. E vélemény nyilván nem független a hetven esztendővel korábbi Avram Iancu-Axente Sever-féle vérengzések, vagy a 18. század végi Horea felkelés magyarellenes pogromjainak

\footnotetext{
${ }^{34} 9 / 2 / \mathrm{a} / 113$ fond 206 . $\mathrm{f}$.

${ }^{35} 9 / 2 / \mathrm{a} / 156$ fond 54 . f.

${ }^{36} 9 / 2 / \mathrm{a} / 156$ fond $46 . \mathrm{f}$.

${ }^{37} 9 / 2 / a / 156$ fond 167 . $f$.

${ }^{38}$ Ld. NAGY 2011 b.
} 
a kollektív tudatba ivódott emlékeitől. Sajnos források híján a képet csak árnyalhatjuk, a valódi arányokat, adatokat nem vázolhatjuk fel. Nagyon sajnálatos, hogy a Kolozsvári Honvéd Hadosztálybíróság teljes vonatkozó iratanyaga nem lelhető fel. Annak segítségével ugyanis legalább a kollaborációs ügyekről nyerhetnénk egy, ha nem is teljes, de a nagy általánosításokat jóval meghaladó szintü képet. Annyi azonban a fennmaradt iratok alapján is bizonyos, hogy az eljárások a kor jogi garanciális elvárásainak messze megfeleltek. (Marasztaló ítéletek egyébiránt jórészt olyan terheltek esetében születtek, akik nagyon nagy valószínüséggel románok voltak, s az ítéletek elől Romániába menekültek.)

De a visszatértek vádjainak nem csak az otthonmaradt románság, hanem az el nem menekült magyarok is céltábláivá váltak. Gyakran gondolták, hogy ezek a románok kiszolgálóivá váltak (, újrománok” lettek), s tevékenyen részt vettek valamennyi bünös cselekedetben. Az elejtett vádak többsége ilyen, rosszindulat táplálta feljelentés következményeként születhetett. A többször említett naplóírót, Balázsovichot is feljelentették. A patikus részletesen leírta naplójában ez ellene felmerült vádakat, melyek alapján őt is a többiekhez hasonló sztereotip vélemények miatt keverték gyanúba. A Szentgyörgyről elmenekült kereskedő, Róth Dávid közlése alapján még az országos lap, Az Est is írt a patikus ,, viselt dolgairól”: ,, a tisztek bementek Pap Antal füszerüzletébe, ahol öt üveg bort fogyasztottak el. Hármat az alezredes, egyet Barabás fóorvos, egyet Balázsovich gyógyszerész fizetett. A román tisztek között lévö kapitány - beszéli Róth-azzal dicsekedett, hogy tud magyarul. Ennek bizonyitékául elénekelte a Ritka búza, ritka árpa. ritka rozs címü népdal első sorait” ${ }^{39}$ Bár a hasonló súlyú ,,bünök” miatt Balázsovichot nem ítélték el, a társadalmi kapcsolatai beszúkültek, sokan bizalmatlanok lettek irányába. Talán ez is hozzájárult, hogy a háború után kitelepült Budapestre, s ott készítette tovább országos hírü sósborszeszét.

Mindezek a körülmények azt jelentették, hogy a székelyföldi társadalom számára „,NagyMagyarország” korszaka véget ért 1916 augusztusában, ha a határokat még időlegesen sikerült is visszaállítani. Végzetes és végletes törésvonalak alakultak ki a társadalomban, mind a magyar etnikumon belül, mind a románok és a magyarok között. Paradox módon ez előbbit az újabb megszállás, majd Trianon feloldotta, a közös nemzetiségi sérelmek kohéziót teremtettek. S a kisebbséggé vált helyi magyarság azzal sem tudott tovább foglalkozni, hogy miként viselkedett a székelyföldi románság az 1916. esztendőben.

\section{FELHASZNÁLT FORRÁSOK ÉS IRODALOM}

\section{Levéltári források}

Kovászna Megyei Állami Levéltár, Sepsiszentgyörgy.

-9/2/a/156. és 157. fond (egykori Föispáni iratok tematikusan rendezett részei).

\section{Irodalom}

IfJ. BERTÉNYI IvÁN (2002): Tisza István és az I. világháború. In Romsics Ignác (szerk.): Mítoszok, legendák, tévhitek a 20. századi magyar történelemről. Budapest, Osiris. 28-86.

Betegh Miklós (1924): Erdély a világháborúban. Dicsőszentmárton, Erzsébet Könyvny.

\footnotetext{
${ }^{39}$ Az Est 1916. szeptember 17.
} 
Csóti CsABA (2004): Az 1916. évi erdélyrészi háború és a Székelyföld. Limes 17. évf. 1. sz. 51-66.

FARKAS ÁDÁM (2011): ,, Van-e új a nap alatt?” Avagy a katonai bűncselekmények törvényi szabályozásának módosulásai a XX. században és egy lehetséges változtatási javaslat. www.hadijog.hu/wp-content/uploads/.../Farkas-Ádám-Kozma-pályamunka-2011.pdf. Hozzáférés: 2017. 05. 31.

KELEMEN Roland (2013): A katonai büntető igazságszolgáltatás szervezete az első katonai bűnvádi perrendtartás és annak módosításai tükrében. Katonai Jogi és Hadijogi Szemle 1. évf. 1. sz. 119-136.

KovÁCs ANTAL (1917): A sepsi református egyházmegye az oláh uralom alatt. Sepsiszentgyörgy, Jókai Ny.

Nagybaczoni Nagy Vilmos (1923): A Románia elleni hadjárat. I. kötet. Budapest, Fráter Ny.

NAGY SZABOLCs (2011a): Az 1916-os román megszállás egy sepsiszentgyörgyi patikus szemével - Balázsovich Sándor naplója. In Boér Hunor - Kinda István - Barti Levente - Kocs Irén Szőcsné Gazda Enikő - Bordi Zsigmond Lóránd - Sztáncsuj Sándor József - Csáki Árpád Demeter Lajos (szerk.): Acta Siculica. A Székely Nemzeti Múzeum évkönyve. Sepsiszentgyörgy, Székely Nemzeti Múzeum. 295-326.

NAGY SzABOLCS (2011b): Egy székely város közállapotai az első világháború végén: A sepsiszentgyörgyi rendőrkapitány 1918. áprilisi felirata a megyei alispánnak. In Boér Hunor Kinda István - Barti Levente - Kocs Irén - Szőcsné Gazda Enikő - Bordi Zsigmond Lóránd Sztáncsuj Sándor József - Csáki Árpád - Demeter Lajos (szerk.): Acta Siculica. A Székely Nemzeti Múzeum évkönyve. Sepsiszentgyörgy, Székely Nemzeti Múzeum. 337-342.

PÁl-ANTAl SÁndor (2003): A csíkiak viszontagságai 1916-ban. In Pál-Antal Sándor: A Székelyföld és városai. Marosvásárhely, Mentor. 198-223.

RAFFAY ERNŐ (1989): A vajdaságoktól a birodalomig. Az újkori Románia története. Szeged, JATE.

SzÁdECZKY-Kardoss Lajos (é.n.): Az oláhok Erdélybe törése és kiverésük 1916-1917. I. kötet. Budapest, Makkay Zoltán Könyvkiadó Vállalata. 